\title{
Physiological and Agronomic Strategies to Increase Mungbean Yield in Climatically Variable Environments of Northern Australia
}

\author{
Yashvir S. Chauhan * and Rex Williams \\ Department of Agriculture and Fisheries (DAF), Kingaroy and Toowoomba, Qld 4610, Australia; \\ rex.williams@daf.qld.gov.au \\ * Correspondence: yash.chauhan@daf.qld.gov.au; Tel.: + 61-741-821-859
}

Received: 4 May 2018; Accepted: 24 May 2018; Published: 26 May 2018

\begin{abstract}
Mungbean (Vigna radiata (L.) Wilczek) in Australia has been transformed from a niche opportunistic crop into a major summer cropping option for dryland growers in the summer-dominant rainfall regions of Queensland and New South Wales. This transformation followed stepwise genetic improvements in both grain yields and disease resistance. For example, more recent cultivars such as 'Crystal', 'Satin II', and 'Jade-AU' have provided up to a $20 \%$ yield advantage over initial introductions. Improved agronomic management to enable mechanised management and cultivation in narrow $(<50 \mathrm{~cm})$ rows has further promised to increase yields. Nevertheless, average yields achieved by growers for their mungbean crops remain less than $1 \mathrm{t} / \mathrm{ha}$, and are much more variable than other broad acre crops. Further increases in yield and crop resilience in mungbean are vital. In this review, opportunities to improve mungbean productivity have been analysed at four key levels including phenology, leaf area development, dry matter accumulation, and its partitioning into grain yield. Improving the prediction of phenology in mungbean may provide further scope for genetic improvements that better match crop duration to the characteristics of target environments. There is also scope to improve grain yields by increasing dry matter production through the development of more efficient leaf canopies. This may introduce additional production risks as dry matter production depends on the amount of available water, which varies considerably within and across growing regions in Australia. Improving crop yields by exploiting $\mathrm{G} \times \mathrm{E} \times \mathrm{M}$ interactions related to cultivar photo-thermal sensitivities and make better use of available water in these variable environments is likely to be a less risky strategy. Improved characterisation of growing environments using modelling approaches could also better define and identify the risks of major abiotic constraints. This would assist in optimising breeding and management strategies to increase grain yield and crop resilience in mungbean for the benefit of growers and the industry.
\end{abstract}

Keywords: Vigna radiata (L.) Wilczek; $\mathrm{G} \times$ E interaction; improvement; model; yield; yield traits

\section{Introduction}

Mungbean (Vigna radiata (L.) Wilczek) is a warm season pulse legume. It is currently cultivated on about six million hectares worldwide, most of which are located in Asia [1]. As a legume, the crop fixes most of its own nitrogen requirement [2] and contributes significantly to improving the sustainability of farming systems [3]. Mungbean also provides an important source of dietary protein for millions of people living in South and South East Asia, many of whom are also vegetarians [4]. Mungbean seeds contains about $\sim 24 \%$ easily digestible protein, is rich in fibre, antioxidants, and phytonutrients, and are consumed whole or split, ground into flour, or used as sprouts [5]. The nutritional composition of the grain makes mungbean an excellent component in a balanced diet with cereals. The growing awareness 
of nutritional benefits has contributed to increasing demand for this crop in recent years. However, due to the low global average yield of $0.4 \mathrm{t} / \mathrm{ha}$, production is failing to keep up with demand with resultant high prices. Increasing the production area of mungbeans to meet this demand is becoming increasingly difficult due to the preference being given to the production of high yielding cereals by small holder farmers [6]. The demand-supply gap for mungbean has created a huge opportunity for other countries, including Australia, to increase the production of this crop to fill export demand, while deriving substantial sustainability benefits to local farming systems.

In Australia, mungbean cultivation began in the 1930s primarily for forage use and as a green manure crop to improve soil fertility in cereal-based farming systems. The crop underwent substantial transformation from 1971 onward when growers started recognising the potential of mungbean as a commercial broad acre grain crop. This transformation gained momentum with the release of locally adapted cultivars such as 'Emerald' and 'White Gold'. Nevertheless, as a grain crop, mungbean was initially considered a low yielding, high risk crop in Australia [7]. This limited its expansion into new areas [8]. However, the cautious attitude of Australian growers towards mungbean began to change with the release of the cultivar 'Crystal' in 2008 and its 20\% yield advantage compared to introduced cultivars such as 'Emerald' and 'White Gold'. In addition, there was an increasing grower recognition of a number of other benefits the crop provided to farming systems. These include a double crop opportunity after a winter crop, control of summer weeds and in enabling shifts from a summer crop cycle to a winter crop cycle. These developments made mungbean the most widely grown summer pulse crop in the summer dominant rainfall regions of Queensland and northern New South Wales.

Mungbean now provides the significant dual benefits to Australian farmers of sustainability and profitability. Coupled with widening market opportunities in Asia, and the availability of new cultivars with a higher yield potential, mungbean production in Australia set a new record of 45,000 MT within a few years after the release of 'Crystal'. With clear indications of the crop's economic potential, the mungbean industry, led by the Australian Mungbean Association (www.mungbean.org.au), set an ambitious annual production target of 100,000 MT. In 2016, mungbean production reached 130,000 MT (Figure 1). Continued breeding innovations, increasing grower confidence and expanding market potential resulted in increasing the production target for industry increasing to 170,000 MT in the same year.

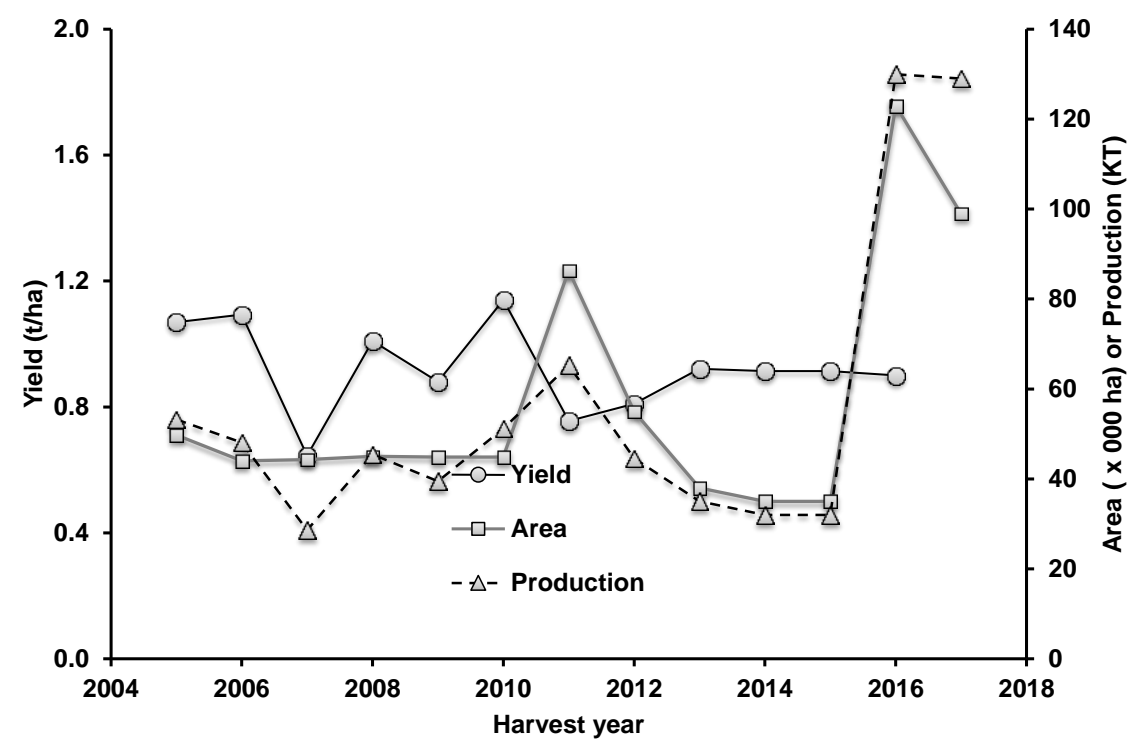

Figure 1. Yield, area, and production of mungbean in Australia (source: agriculture.gov.au/abares/ research-topics/agricultural-commodities). 
Notwithstanding a several-fold increase in mungbean production, the average yield of mungbean on Australian farms is still less than one $\mathrm{t} / \mathrm{ha}$, despite the yield potential for mungbean being around three $t /$ ha [9]. Similar yields have also been harvested in Sri Lanka [10]. Even in trials conducted under relatively well-managed conditions, yield is low. For example, in experiments conducted by breeders from 2012 to 2017, yields averaged only $1.13 \mathrm{t} /$ ha compared to $1.90 \mathrm{t} /$ ha potential yields as simulated by the Agricultural Production Systems Simulator (APSIM) model for the same period, representing a yield gap of $40 \%$. This yield gap is likely not due to the lack of available water, but instead attributable to biotic factors such as insect pests, diseases as well as harvest losses including shattering. Low yields could make the crop less competitive compared to other broad acre option when mungbean market prices are low.

The preferred avenue of achieving further improvements in mungbean production in Australia should be by increasing average yield. The current focus of mungbean breeding is mainly to enhance yield and resistance of the crop to major diseases such powdery mildew, halo blight, and tan spot [11]. Resiliencies to drought and heat stresses, which are also major contributors to variable yield of mungbean [12], are being indirectly enhanced through multi-location testing in conjunction with advanced statistical approaches. To accomplish increases in average yield in the face of drought and heat stress, however, focussed efforts based on an improved understanding of the agronomy and physiology of this crop are required.

Here we review some of the past work on mungbean physiology and agronomy including possible opportunities to increase yield in new mungbean cultivars and close the yield gap in different production environments. We also propose a few new areas of research that could potentially assist in developing new high yielding cultivars based on an improved physiological understanding of the crop. We also discuss how the application of a mungbean simulation model could assist in better characterising the frequencies of major abiotic constraints, understand the basis of genotype $\times$ environment $(G \times E)$ interactions and determine the value of useful traits.

\section{Mungbean Evolution and Diversity}

Mungbean belongs to the subgenus Ceratotropis in the legume genus Vigna, the tribe Phaseoleae, and the family Fabaceae. The crop has a diploid chromosome number of $2 n=2 x=22$. It likely originated in India [13]. Vavilov (1951) suggested the primary genetic centre of diversity for mungbean was the central Asian region, with India as the probable centre of domestication [14]. Lukoki, et al. [15] proposed that $V$. radiata var. sublobata (Roxb.) Verde that occurs in the wild in India and crosses readily with $V$. radiata, is the wild progenitor of mungbean.

The mungbean crop in Australia consists of two main crop types, one with green seeds called green gram (Vigna radiata Wilczek) and another with black grains called black gram (Vigna mungo Hepper). Both species are cross compatible to a limited extent [16]. In this review, the primary emphasis is on green gram, which is the dominant type of mungbean grown in Australia. Black gram mungbean is only a minor crop in Australia. Current cultivars of green gram mungbean are short-statured with short growing duration of generally less than 100 days.

Yimram, et al. [17] evaluated 9 qualitative and 21 quantitative traits in 340 diverse cultivated mungbean collections at AVRDC-the World Vegetable Centre, Taiwan, to assess the extent and pattern of their diversity in yield-related characteristics. The germplasm they compared displayed a wide range of diversity for most traits evaluated. They found high genetic variability, moderate to high broad sense heritabilities in yield components including 100-seed weight, seed weight per plant, and the number of pods per plant. Traits such as plant height and days to flowering and maturity also showed high genetic variability and broad sense heritabilities, while genetic advance was greatest for plant height, but relatively low for days to flowering and maturity. A significant limitation to yields in mungbean is often ascribed to a narrow genetic base for released cultivars [18]. Since Indian germplasm has been frequently used in mungbean breeding programs in the past, it should be diversified further by using germplasm from other regions, including West Asia [17]. 
Mungbean in its native environments in Asia is primarily a subsistence crop. The short season nature and indeterminate flowering habit of older cultivars are advantageous in subsistence cropping systems, but not desired traits for high yield potential in commercial scale production. High and stable yields are major objectives for the mechanised production system in Australia, and hence traits that contribute to these objectives need to be improved. How to best exploit genetic variability available in green mungbean to develop higher yielding cultivars remains a matter of considerable interest among mungbean scientists $[19,20]$. Major targets for mungbean improvement include a stable potential yield of $>2 \mathrm{t} / \mathrm{ha}$, a maturity duration of around 60 to 75 days and synchronous maturity for ease in harvesting [21]. Other desirable features include seed size (50 to $60 \mathrm{~g}$ for 1,000 seeds instead of the 25 to $30 \mathrm{~g}$ for 1,000 seeds produced by traditional types), resistance to significant biotic stresses, a compact canopy, high harvest index (HI), photoperiod insensitivity, and increased determinacy.

In Australia, over $90 \%$ of mungbean production is from newly developed cultivars such as 'Crystal', 'Satin I', and 'Jade-AU' bred using conventional breeding approaches. These cultivars already incorporate some of the features mentioned previously. While likely possessing sufficient yield potential, they remain highly variable resulting in low average yields. To develop new cultivars with improved yields and stability especially against diseases, locally-adapted lines are being enhanced with genes sourced from introduced diversified germplasm [11]. However, the blueprint for achieving higher yields in the mungbean crop is still not entirely clear.

Mungbean yield improvement achieved using conventional breeding approaches, as in the past, could still deliver yield increases, but broadening of improvement efforts to also include an ideotype approach is also required to make desired gains in yield and stability [22]. A small genome size $(\sim 600 \mathrm{Mb})$ and short-duration make mungbean highly suitable for yield improvement using other approaches. Learnings from other legumes may also be useful in targeting yield improvements in mungbean. Kang, et al. [23]—in providing the first draft genome sequence for mungbean—found that most of genes in genomic regions were in synteny with soybean.

However, it is critical to identify and understand physiological limitations to yield in mungbean before identifying opportunities or solutions to overcome them. To do this, we have considered mungbean crop growth and its development in a physiological framework and assessed the potential to increase the efficiency of each component of this framework in enhancing its potential contribution to grain yield in mungbean.

\section{Physiological Framework of Yield in Mungbean}

\subsection{Crop Establishment and Development}

Establishing an optimum plant stand of about 30 plants $/ \mathrm{m}^{2}$ is an essential requirement to obtain high yields in mungbean [24]. Poor establishment, in part due to poor germination, is often a major reason for poor yields in marginal environments [25]. Germination in mungbean is epigeal and cotyledons have to emerge out of the ground to support seedling growth. This type of germination could limit crop establishment in soils with low moisture and high strength [26] such as high-clay and rapidly-crusting soils especially under high temperatures. However, in quick drying and crusting red-earth soils of Katherine in northern Australia, mungbean was found to establish better than soybean and cowpea even at $8 \mathrm{~cm}$ depth despite having similar germination characteristics [27]. While seedling vigour could play a role in emergence in crusting soils, this was found to have no relationship with the final yield in mungbean [28]. In self-cracking clay soils, mungbean establishment is generally not an issue [29]. In such soils, ultimate crop performance instead reflects the suitability of growing conditions following crop establishment.

Once established, yield formation in mungbean depends on the crop's ability to produce and partition dry matter into grain yield (Figure 2). This follows a series of development stages in the plant. During these stages, the plant develops a leaf canopy, intercepts incident solar radiation, converts the absorbed radiation into assimilates, and partitions these assimilates into various plant components, 
including roots, pods, and seeds. Water and nutrients needed by plants can limit these processes if plant demand exceeds available supply. The transition from one developmental stage to another occurs in response to temperature and photoperiod, which also sets the potential dry matter production and partitioning into different components including grain yield. Manipulation of the efficiencies of these processes, as well as the duration they last, to match the environmental resources offers an opportunity for improving grain yield. The potential to manipulate some of these processes, however, seems greater than others (Figure 2).

\section{Physiological determinants of grain yield}

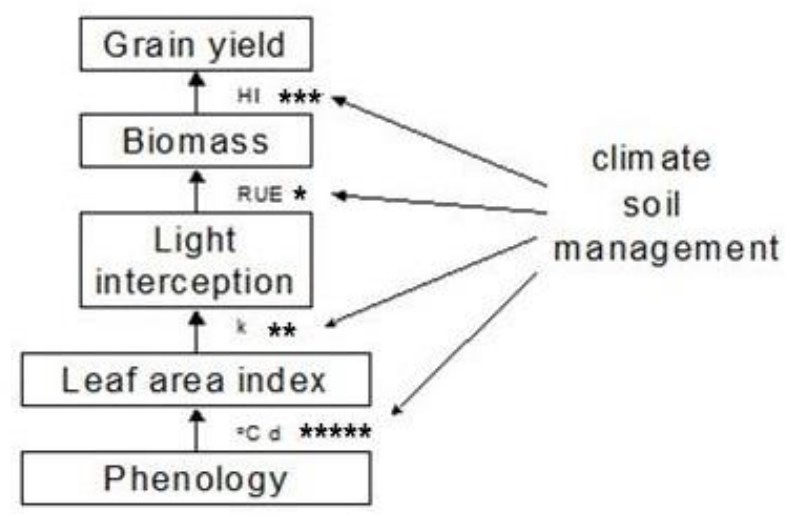

Figure 2. A physiological framework for grain yield in mungbean and the potential for genetic/agronomic manipulation of photo-thermal sensitivity $\left({ }^{\circ} \mathrm{C} \mathrm{d}\right)$, light extinction coefficient $(k)$, radiation use efficiency (RUE), and harvest index $(\mathrm{HI})$ is compared through the number of asterisks.

\subsection{Crop Phenology}

The time taken by mungbean plants from sowing to maturity is an essential determinant of yield as it enables plants to match developmental processes with the growing environment, as well as set yield potential. It also helps determine the crop's fit into different cropping system windows and the timing of various field operations including harvesting. Crop duration changes in response to varying weather conditions from place to place and in different sowings and seasons. Therefore, being able to predict crop duration is important in understanding and potentially addressing the causes of yield variability in mungbean.

A basic understanding of major factors that determine crop duration in mungbean has been outlined by a range of authors $[30,31]$. Cultivated mungbean is a quantitative short day plant and the rate of progress toward flowering can be described using a series of linear models incorporating temperature and photoperiod effects [30,32]. However, a more flexible approach to predict crop duration, such as used in the APSIM model, is to consider phenology as consisting of different stages of development [33]. The different growth stages prior to flowering include sowing to emergence (SE), emergence to the end of the basic vegetative phase (BVP), a photoperiod-induced phase (PIP) which ends at floral initiation, and a floral development phase (FDP) which ends at 50\% flowering (Figure 3 ). The transition from emergence to BVP and from PIP to FDP occurs independently of photoperiod in mungbean and hence is not affected by time of sowing even in photoperiod-sensitive cultivars. Photoperiod influences only at PIP. This contrasts the approach of [30] that used mean photoperiod for the entire pre-flowering period to determine flowering time. In the APSIM mungbean model, transitioning through three stages of development including SE, BVP, and FDP has been modelled as a function of temperature (thermal time target, ${ }^{\circ} \mathrm{C} d$ ); and during PIP as a function of temperature and photoperiod $(t$ and $p)$. The thermal time targets for different stages are derived through optimisation 
and field data from multiple sowing times and environments. The thermal time addition for mungbean depends on three cardinal temperatures: base $\left(7.5^{\circ} \mathrm{C}\right)$, optimum $\left(30^{\circ} \mathrm{C}\right)$, and maximum $\left(40^{\circ} \mathrm{C}\right)$.

\section{Mungbean phenology}

\section{Developmental stages}

Sowing Emergence

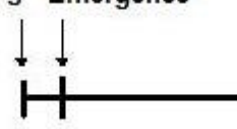

Floral initiation

\begin{tabular}{l|l} 
End basic vegetative stage $\quad$ lst Flowering Start podfilling
\end{tabular}

Physiological maturity

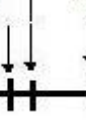

T

525
T

400

Figure 3. Mungbean phenological stages and their thermal time targets $\left({ }^{\circ} \mathrm{C} d\right)$ for the cultivar 'Emerald'. The thermal time target for 'Crystal' is similar to 'Emerald'. The total duration of $1200{ }^{\circ} \mathrm{C}$ d is the sum thermal time targets of all stages.

There is no evidence of vernalisation requirement in mungbean, which can also affect phenology $[31,34]$. The phenology routines of the APSIM model calculate each day's thermal time (in degree-days) from three-hourly air temperatures interpolated from the daily maximum and minimum temperatures in the cardinal temperature range. In short-day plants, the duration of the PIP phase increases as photoperiod increases above the critical photoperiod $\left(P_{c}\right)$. PIP is short if it is completed before photoperiod is $>P_{c}$. PIP increases with photoperiod above a base photoperiod $P_{b}$. For individual cultivars, the duration of PIP is dependent on daily photoperiod and photoperiod sensitivity $\left(P_{s},{ }^{\circ} \mathrm{C} \mathrm{d} / \mathrm{h}\right)$.

In quantitative short-day cultivars, there is no further delay in floral initiation when photoperiod exceeds $P_{c}$. If PIP occurs during or after $P_{c}$ is reached, it results in a more extended PIP phase. In contrast, in qualitative short-day cultivars, floral initiation does not occur when photoperiod is above $P_{c}$, and the plant initiates only when photoperiod falls below $P_{c}$. If photoperiod is $>P_{c}$ before PIP is completed, floral initiation is delayed until photoperiod is $\left\langle P_{c}\right.$ again.

$P_{c}$ vary between 11.5 and $12.5 \mathrm{~h}$ among different cultivars and tends to increase with temperature [35]. The commercial mungbean cultivars grown in Australia do not respond to photoperiod during PIP [36] as probably their $P_{c}$ is higher than those reported by Imrie and Lawn [35]. Photoperiod sensitivity, however, is widespread in mungbean with over $50 \%$ of the 1273 green mungbean tested in Taiwan found to be photoperiod-sensitive in the 12 to $16 \mathrm{~h}$ photoperiod range [7].

In the phenology model for mungbean embedded in the APSIM model as described by [33], daily thermal time $(t)$ is accumulated during each stage of development until a threshold is reached and then the development progresses to the next stage [31]. The thermal time for BVP $(v)$ for each cultivar and is uninfluenced by photoperiod. Thermal time requirements for BVP and FDP are derived in the model through optimisation for each cultivar. However, the thermal time required to complete PIP ( $i)$ is recalculated for each day during this phase as a function of daily photoperiod $(p)$, photoperiod sensitivity of the cultivar $\left(p_{\mathrm{s}}\right.$ expressed in units of ${ }^{\circ} \mathrm{C} \mathrm{d} / \mathrm{h}$ ) and the optimal photoperiod $\left(p_{b}\right)$. The following equations express the relationships

$$
i=p_{s}\left(p-p_{b}\right)
$$

where, for photoperiod $\leq p_{b}, p=p_{b}$ and $i=0$, and for photoperiod $>$ critical photoperiod $\left(p_{\mathrm{c}}\right), p=p_{c}$, the progress $r$ through PIP can be calculated as 


$$
\mathrm{r}=\Sigma(t / i),
$$

PIP ends when $r$ is $\geq 1$. If PIP is completed and $p<p_{c}$, then thermal time from emergence to flowering is calculated as

$$
f=v+i+d
$$

where $d=$ is the thermal time required to complete FDP, If photoperiod at the calculated completion of PIP is $>p_{c}$, then

$$
f=v+i+i d+d
$$

where id represents the thermal time delay in completing of PIP until photoperiod is $\leq p_{c}$. The thermal time requirement from the end of vegetative phase to the end of PIP, modulated by photoperiod, assists in defining quantitative short day responses in mungbean.

Following flowering, the mungbean plant goes through a lag phase before commencing a linear phase of grain filling, followed by a period between the end of grain filling and physiological maturity and a harvest-ripe period before grain harvest (Figure 3). The transition of plants through these stages is also based on thermal time targets.

The APSIM phenology model is simple compared to more complex rate-based models [30,35]. However, the prediction of flowering and maturity times using the phenology model embedded in the APSIM model was found to be reasonably accurate [10,37]. In Chauhan and Rachaputi [37], the mungbean cultivar 'Crystal' required a total of $1200^{\circ} \mathrm{C}$ d from sowing to maturity and this was similar to the older cultivar 'Emerald' already parametrised in APSIM.

There is a need to consider photoperiod effects not only in terms of their influence on flowering, but also their direct effects on yield which sometimes become evident even when there are no visible effects on flowering time [38]. These effects on yield could result through flowering synchrony, which in turn could affect dry matter partitioning as documented for common beans [39]. It is clear that a better understanding of the effects of photoperiod in driving dry matter partitioning of mungbean is required to improve yield in this crop.

A change in the basic vegetative phase and photoperiod sensitivity of the crop could easily change crop duration. However, the benefit of any increase or decrease in crop duration on grain yield would depend on the type of growing environment. In high frequency terminal stress environments, a decrease in crop duration will be appropriate, with the opposite true in environments with lesser frequency of terminal drought. As such environments are unpredictable, the crop's ability to adjust its phenology to better adapt to the environment will also be important. Improving phenotypic plasticity in mungbean phenology responses to the environment could provide another suitable breeding target to increase grain yields and crop resilience in mungbean.

\subsection{Leaf Area Development}

Mungbean leaves are broad, have a tri-foliate structure and overlapping horizontal orientation that tends to limit light distribution into the canopy. Mungbeans with narrower leaflets would allow better light distribution within the canopy. Indeed, a mungbean cultivar with narrower leaves and higher light interception was found to have a higher yield potential compared to a mungbean with broader leaves [40].

The formation of the leaf canopy to intercept solar radiation depends not only on the leaf size but also on the rate of leaf formation and senescence. The leaf appearance rate depends upon temperature. Leaf senescence rate depends on the remobilisation of assimilates by developing pods as well as temperature. Thus, higher temperatures within the cardinal range early in the life of a plant can result in quicker canopy development, but similar conditions following canopy development can enhance senescence, especially under conditions where soil moisture is limited. Genetic variation in leaf appearance rates and leaf senescence could be useful traits to investigate further to maintain leaf area and support dry matter accumulation and grain filling. 
Mungbean was reported to attain a leaf area index (LAI) of up to 6 by the 50th day after sowing, or shortly after flowering, producing a grain yield of $2.5 \mathrm{t} / \mathrm{ha}$ from 35 plants $/ \mathrm{m}^{2}$ in an Australian sub-tropical environment [41]. In the same environment, a LAI of 9 was attained by day 60 for a soybean crop that produced $4 \mathrm{t} / \mathrm{ha}$. A LAI of 6.5 was achieved on the 40 th day after sowing for a cowpea crop that produced $2.9 \mathrm{t} / \mathrm{ha}$. The critical leaf area index was 3 to 4 [42] which can enable a crop to intercept over $90 \%$ of the incidence radiation during pod filling.

Planting at narrow rows of $0.5 \mathrm{~m}$ can accelerate closer canopy development and achieve greater light interception when compared to wider rows of $1 \mathrm{~m}$ [24]. However, grain yields in mungbean appears generally not to be limited by leaf area development in Australia [43]. In such environments, the benefits that research has identified from the use of narrow rows in mungbean could be for other reasons, such as reducing soil moisture losses from evaporation. A study from Taiwan, however, reported inadequate leaf area development as the primary limitation to yield in mungbean [44]. Such limitations could arise in marginal environments, such as after a rice crop with limited moisture availability and soil compaction issues. Drought may also affect leaf expansion and appearance rates [45]. However, it is uncertain whether genetic variation exists for these traits in and among specific environments.

Muchow, Robertson, and Pengelly [41] found that there was a smaller reduction in LAI during the pod fill stage in mungbean compared to cowpea and particularly soybean grown in the same environment. A more modest decrease in LAI of mungbean by maturity often necessitates its forced senescence through desiccation before crop harvest.

All the currently grown mungbean cultivars in Australia including 'Crystal', 'Celera', 'Satin-II', and 'Jade-AU' are morphologically determinate in that the apex of the main stem or a branch always differentiates (developed) into a flower bud (Figure 4). Determinacy essentially restricts the further growth of the main stem. In adverse growing conditions, as well as during recovery from stress, this trait can constrain canopy development—especially when mungbeans are grown in wider $(\sim 1 \mathrm{~m})$ rows. The inability to occupy available space limits the ability of determinate mungbean cultivars to accumulate more biomass under favourable growing conditions compared to indeterminate (black gram) cultivars [34]. The comparative advantage of determinate and indeterminate growth habits for different growing situations can be simulated in the APSIM model by changing allocation of dry matter to seed [46]. This can assist in determining the relative value of determinacy in different cropping systems and environments.

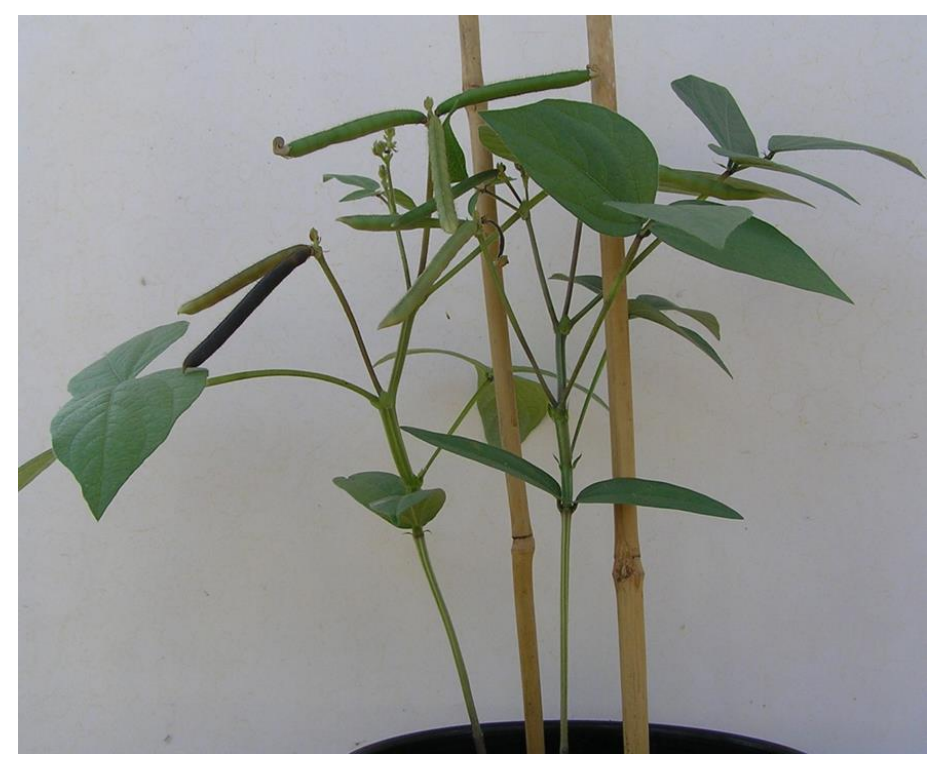

Figure 4. Mungbean plants grown in pots showing trifoliate leaves and determinate morphology. 


\subsection{Biomass Accumulation}

Biomass (dry matter) is the most important yield determinant of current mungbean cultivars with over $90 \%$ of the total variation in yield being accounted by this trait [24]. Biomass accumulation is a function of LAI, light extinction coefficient, the duration of light interception, and radiation use efficiency (RUE). Increasing plant density (plants $/ \mathrm{m}^{2}$ ) increases in leaf area and hence crop biomass. However, too great a leaf area may prove disadvantageous during later stages of crop growth as it could lead to water deficit. Hence, the concept of an optimum plant population arises [47].

Another opportunity to increase biomass is to improve light distribution within the canopy. The light extinction coefficients used in the APSIM model for mungbean vary between 0.30 and 0.58 for 100 to $20 \mathrm{~cm}$ row spacing respectively [9,31]. The light extinction coefficient for the mungbean cultivar 'Crystal' may exceed these figures since its yield advantages over previous mungbean cultivars appears due to more vigorous growth. This was highlighted by an under prediction of dry matter for a 'Crystal' crop (Figure 5) when using the original extinction coefficients derived from older cultivars parametrised in the APSIM model. Prediction of dry matter for 'Crystal' improved when the light extinction coefficient increased from 0.30 to 0.45 . A lower extinction coefficient could result in more radiation reaching to the ground especially in wider rows. An increase in the extinction coefficient improved predictability $\left(R^{2}\right)$ of fractional interception in narrow and wide rows of mungbean to $83 \%$ from less than 50\% [24]. Differences in extinction coefficients leading to better prediction of light interception and dry matter for 'Crystal' indirectly suggests that plants of 'Crystal' may retain greater leaf area during grain fill than earlier varieties. This would provide major advantages and could explain much of the yield improvements measured for 'Crystal' mungbeans over earlier varieties.
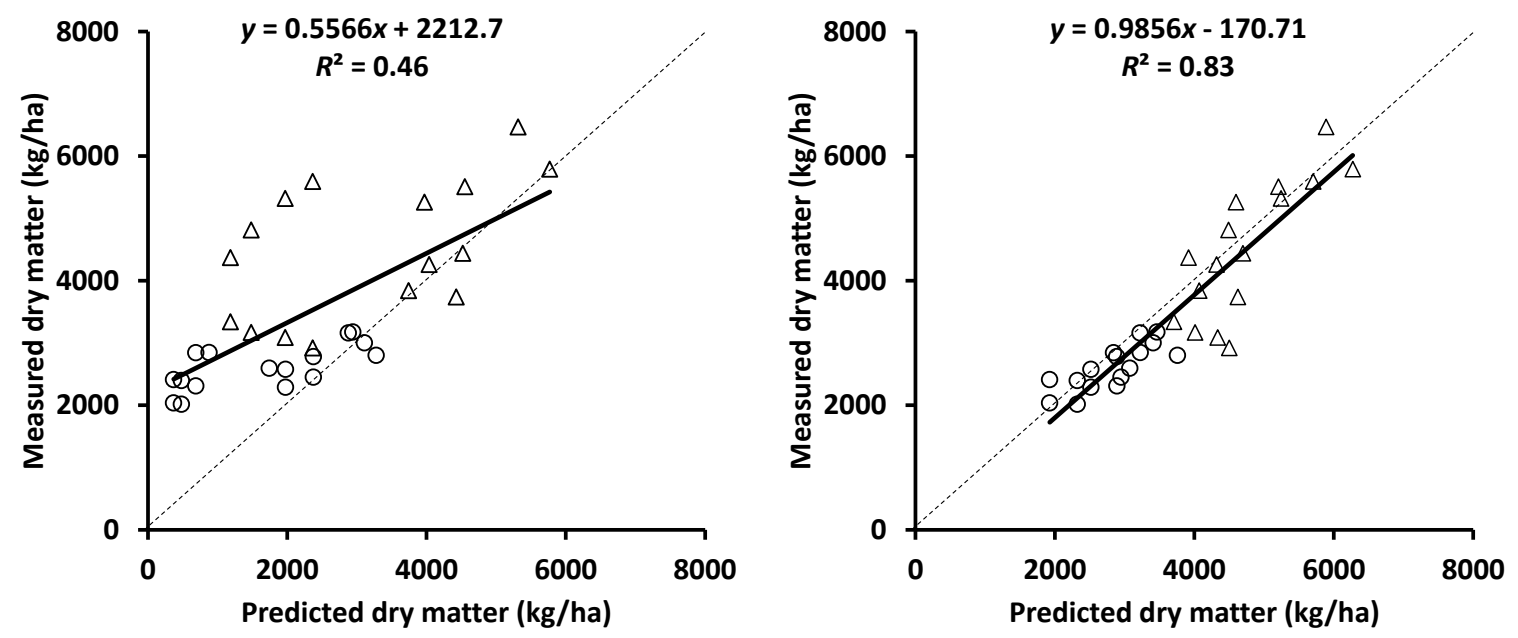

Figure 5. Relationship between observed dry matter and that predicted using the APSIM mungbean model with extinction coefficients ranging from 0.3 to 0.58 (left panel) and 0.45 to 0.58 (right panel) for the mungbean cultivar 'Crystal' at 57 days after sowing at Emerald (circle) and 97 days after sowing at Hermitage (triangle) [48].

With a trend to plant mungbean in narrower rows, there remains an increasing need to identify target light extinction coefficients that improve light distribution within a canopy. Lee, Lee, Kim, Yoon, Bak, Park, Bang, Moon, Oh, and Min [40] suggested that a mungbean cultivar with narrow leaves with a greater penetration of light into the canopy might produce higher yields. Exploiting variation in the light extinction coefficient that results from variations in leaf morphology and row spacing could be a focus for future physiological research in mungbean.

Another potential avenue to increase dry matter is through improvement in the radiation use efficiency (RUE). The RUE of $0.94 \mathrm{~g} / \mathrm{MJ}$ in mungbean was comparable to that of soybean and cowpea, and this baseline RUE was unaffected by soil moisture [24,49]. The relative similarity in RUE with other 
tropical legumes, and the stability of baseline RUE across environments, suggests that relatively low dry matter production in mungbean is unlikely to be due to low RUE, but possibly due to the shorter duration of this crop. There could be some scope for improving RUE by improving leaf photosynthetic capacity. However, given the experience in other tropical legumes, this opportunity is likely to be limited [50]. Therefore, the best chances to increase biomass production in mungbean could be by ensuring the earlier attainment of a critical LAI of 3-4 [42], increasing crop duration and/or developing cultivars with smaller leaflets that allow better light distribution within the mungbean canopy.

Irrespective of the strategy used for increasing biomass, resultant increases in yield will still likely vary substantially. This is because dry matter production in mungbean is a function of water use and availability, which is often very variable [51]. Increasing biomass to increase grain yield is likely to be a more successful strategy in more favourable moisture environments. Stress due to lack of water at the soil surface hastens crop maturity in mungbean and restricts leaf area development, leaf expansion, and stem branching, while leaf senescence increases. Developing mungbean plants with a root system that is able to draw more moisture from the soil could help reduce this extreme phenological and morphological sensitivity to water stress situations [52].

\subsection{Biomass Partitioning}

Harvest index represents the efficiency of biomass partitioning into yield, and is the ratio between yield and the total above ground biomass. Harvest index for mungbean is around $0.3[9,53,54]$. This is low compared to about 0.5 in soybean and peanuts. In soybean and peanuts, a deliberate selection for biomass partitioning to yield has apparently contributed to the development of higher yield potential [41,55-57]. In mungbean, attempts to increase HI have not been successful despite being recognised to be a significant limitation to achieving high grain yield [7,50]. Harvest index needs to be a major target for improvement in crops where it is less than 0.5 [58]. The notion that yield-based selection will indirectly select for increased $\mathrm{HI}$ may not necessarily be true. Longer crop durations or better canopy development rather than HI may instead drive increases in yield achieved due to increased dry matter production in yield based selection.

The relatively low $\mathrm{HI}$ in mungbean suggests there may be considerable scope for improvement [59]. The crop's phenology interacts with growth habit to determine crop duration in influencing dry matter partitioning [60]. Cultivars with a determinate growth habit could partition dry matter into yield more efficiently than indeterminate cultivars, especially in terminal drought situations [46]. Under extended crop duration, flowering in mungbean is less synchronous. The lack of flowering synchrony in mungbean, resulting from day length being longer than the critical photoperiod, is the key contributor to low HI. This also leads to the formation of multiple flushes of flowers [9]. The critical photoperiod for efficient partitioning could be different compared to that for flowering. An effective way to maximise HI could be to choose an appropriate planting time that ensures a crop grows at photoperiods below its critical photoperiod to allow rapid ontogenetic development [61].

Lack of flowering synchrony can arise not only as a result of photo-thermal sensitivity in dry matter partitioning [54], but also from soil moisture conditions [9]. It appears mungbean may not possess the required traits that dictate a strong commitment to drawing down nitrogen from vegetative tissues and putting it into seed, especially under high soil moisture conditions [54]. This tendency is more strongly expressed when day length is longer than the critical photoperiod. In a monsoonal tropical environment, where photoperiod may be less than that required to increase flowering synchrony, dry matter partitioning into yield may still be poor due to soil high moisture levels that encourage greater vegetative growth [62]. We need to understand how soil moisture contributes to the lack of flowering synchrony in mungbean and its possible mitigation, as this trait is not very prominent in soybean - a closely related legume.

There are differences in the timing of accumulation and remobilisation of photo-assimilates in mungbean. Cultivated types tend to depend more on current photosynthesis during the reproductive stage while reserving assimilates accumulated before flowering for the second flush [54]. In contrast, 
landrace cultivars tend to remobilise dry matter and $\mathrm{N}$ reserves accumulated before flowering and tend to exhaust much of $\mathrm{N}$ in the leaves before the active pod-filling period. It is possible that a combination of the two traits will be required to maximise yield from the first flush of pods and ensure that most of the leaves senesce by maturity. It is unknown whether differences in the remobilisation of assimilates occur in response to differential photo-thermal sensitivity [41].

Photo-thermal sensitivity is the key source of $G \times E$ interactions in mungbean. This can contribute three times more variation in grain yield compared to genotype alone [63]. This sensitivity contributes to the specific adaptation of mungbean cultivars $[64,65]$ and their wild relatives at different latitudes [34,66]. Variation in photo-thermal sensitivity can be exploited to increase $\mathrm{HI}$ in mungbean. A few relevant ideas obtained on other legume crops (as described below) could also possibly be applied to mungbean.

Grain yield for legumes is the product of optimum flowering time to ensure complete canopy development and a higher HI. Photo-thermal sensitivity can affect both traits. In soybean and mungbean, long photoperiods are known to reduce HI, even in cultivars that are supposedly insensitive to time to flowering $[38,67]$. In peanut also, where flowering is insensitive to photoperiod, extended day lengths can reduce HI [68].

It appears that tropical legumes have improved dry matter partitioning to grain when they are moved from higher latitudes of adaptation to lower latitudes [50]. These legumes respond similarly in late sowings that experience more inductive day length, whereas the effect of inductive photoperiod on biomass accumulation is the opposite of HI. Chauhan, et al. [69] found that short-duration pigeonpea (Cajanus cajan) cultivars adapted to sub-tropical environments at $29.1^{\circ} \mathrm{N}$ latitudes when grown at lower at $17.3^{\circ} \mathrm{N}$ latitude resulted in an over $35 \%$ improvement in HI. There was a small reduction in crop duration, and hence the total dry matter, but the increase in HI more than offset the decline in dry matter. This work led to a short duration cultivar developed for sub-tropical environments being released for cultivation in tropical environments, although initially developed for sub-tropical environments [70].

This transition of a crop towards tropical latitudes from its zone of adaption appears to work well when the shortening of crop duration and reductions in dry matter production are relatively minor relative to increases in HI. However, when a transition leads to significant decline in crop duration, reduced grain yields invariably result. This is mainly due to flowering occurring too rapidly and plants failing to accumulate enough dry matter to support grain [50]. Indeed in pigeonpea, Chauhan, et al. [71] found that when lines selected for the temperate environment of Minnesota $\left(45^{\circ} \mathrm{N}\right)$, USA were grown at Patancheru $\left(17.3^{\circ} \mathrm{N}\right)$ in India along with local cultivars, their grain yields declined significantly due to the shortening of their crop durations. Some temperate adapted lines, however, gave higher yields compared to local cultivars with a protracted crop duration of 10 to 15 days achieved using artificial day length extension. Day lengths were adjusted on a weekly basis was to mimic a $45^{\circ} \mathrm{N}$ day length before the September equinox. In this experiment, lines adapted to temperate environments partitioned more dry matter into yield under extended day length compared to the tropically-adapted lines.

A similar example of a successful transition from temperate to tropics is that for soybean lines introduced in Southern Queensland ( 25 to $\left.27^{\circ} \mathrm{S}\right)$ Australia from the mid-west $\left(40^{\circ} \mathrm{N}\right)$ of the USA [72,73]. Initially, these US-bred lines performed poorly in the Australian sub-tropics. When grown under extended day lengths, yields of these lines increased from 4.9 to $6.1 \mathrm{t} / \mathrm{ha}$ in the Australian subtropical environment. Exposure to an extended photoperiod delayed maturity of these lines by about 10 days. Subsequently, crosses of these exotic cultivars with a cultivar having a long juvenile phase led to extension of crop duration similar to an artificial photoperiod extension. This increased both plant growth as well as grain yield [73].

We know that tropical legumes, including mungbean and its wild relatives adapted to sub-tropical or temperate latitudes, are relatively less photoperiod sensitive than some tropically adapted crops $[66,74-76]$. Not only they are less photoperiod sensitive, their basic vegetative phase is also of 
shorter duration than in some crops [75]. These photo-insensitive plants are primed to partition more dry matter into yield under long days compared to sensitive cultivars adapted to tropical latitudes. This ensures that they produce seed before temperatures and day length becomes too low to support their growth. The cultivation of temperate-adapted cultivars at lower latitudes with similar levels of photoperiod sensitivity as they exhibit at higher latitudes enables these plants to more efficiently partition dry matter into yield. In this respect, their performance could even surpass plants of the same cultivar that have not experienced longer days at higher latitudes. This could reflect the epigenetic modification of photoperiod and partitioning genes through DNA methylation. Takeno [77] suggested that the DNA methylation could regulate expression of photoperiodic flowering genes and some of the effects could be heritable. It is possible that seed from plants retains an 'epigenetic memory' of the longer day lengths of higher latitudes to maximise the chances of seed production in the next season, even when they experience shorter days. There is a need to test this hypothesis and ascertain whether a change from higher to lower latitude could overcome physiological barriers to high HI. If so, it would be useful to identify the mechanism involved so that it could be exploited.

The production of multiple flushes of pods in mungbean may be a remnant trait carried over in mungbeans evolution from subsistence agriculture in the tropics with monsoonal climate [54]. This could also reflect poor dry matter partitioning into yield [9]. Mid-season moisture stress followed by recovery during first flush of flowering may also lead to the formation of multiple flushes in mungbean following an increase in leaf area [9]. The development of mungbean cultivars that maximise pod production from the first flush of flowers under non-limiting moisture conditions may be desirable to make a crop of relatively fixed duration that is unaffected by soil moisture status or photo-thermal sensitivity in partitioning. Such a 'season-bound' crop would improve the predictability of its cropping period.

One approach to achieving formation of only a single flush could be to synchronise pod set during the first flush of flowers [50]. However, pod synchrony resulting from the earliest formed flowers of the first flush was found to be negatively associated with yield in mungbean [78]. This probably reduced the amount of assimilate build up for further growth. Flower shedding in mungbean has been found to result from competition for assimilate from roots which also grow rapidly at the same time as flowering commences [79]. It may, therefore, be better not to convert the earliest formed flowers into pods as they may contribute to shedding of later formed flowers [53,79]. This view is supported by the fact that occasionally the lack of pod formation from the initially formed flowers due to insect pressure can result in a compensatory flush with resulting higher grain yield [80]. In chickpea, where little flower drop is observed, the earliest formed flowers are always sterile and therefore known as pseudo flowers [81]. In some pigeonpea derivatives of crosses with wild relatives, long photoperiods were found to induce sterility of early formed flowers, which became fertile to set pods synchronously when day length became shorter than the critical photoperiod [82]. Hence the possibility of delaying pod set by a certain number of days to achieve greater pod synchrony and yield could be investigated in mungbean, and if found to be beneficial, should be incorporated into new cultivars to maximise grain yield.

\section{Genotype $\times$ Environment Interactions}

The above discussion suggests that the environment has a strong influence on many mungbean traits including flowering time, dry matter production, and partitioning. The impact of main effects of environment (E) and the interactions on yield of genotypes $(G)$ can be summarised through the classical equation

$$
\text { Yield }=\mathrm{G}+\mathrm{E}+(\mathrm{G} \times \mathrm{E})
$$

Analysis of international mungbean trials suggested the presence of strong $\mathrm{G} \times \mathrm{E}$ interactions [83], some of which were related to physiological traits including time to flowering and maturity. Time to flowering in mungbean was subject to both genetic [84], and environmental control [36]. The photo-thermal control on flowering time has been extensively modelled [31,36]. It should therefore 
not be difficult to overcome negative $\mathrm{G} \times \mathrm{E}$ interactions by appropriate matching of phenology to the environment if flowering time is the main contributor of such interactions.

Since there is only small variation in time to flowering among mungbean cultivars currently available to Australian growers, it is unlikely to be a significant contributor to $G \times$ E interactions in yield trials conducted in Australia that use these cultivars or their progenies. Indeed, a dataset analysed from some mungbean varietal trials suggested that there may not be significant changes in cultivar rankings in yield performance across several Australian environments [48]. This was well supported by model simulations (Figure 6). However, it is possible that with the growth of mungbean industry, breeders will start to widen specific adaptation to different environments including improving tolerances to drought, high temperature, and sub-soil constraints. Chauhan and Rachaputi [37] have characterised mungbean-growing environments of northern New South Wales and Queensland with respect to drought. This could assist in identifying widely and specifically adapted cultivars of mungbean.
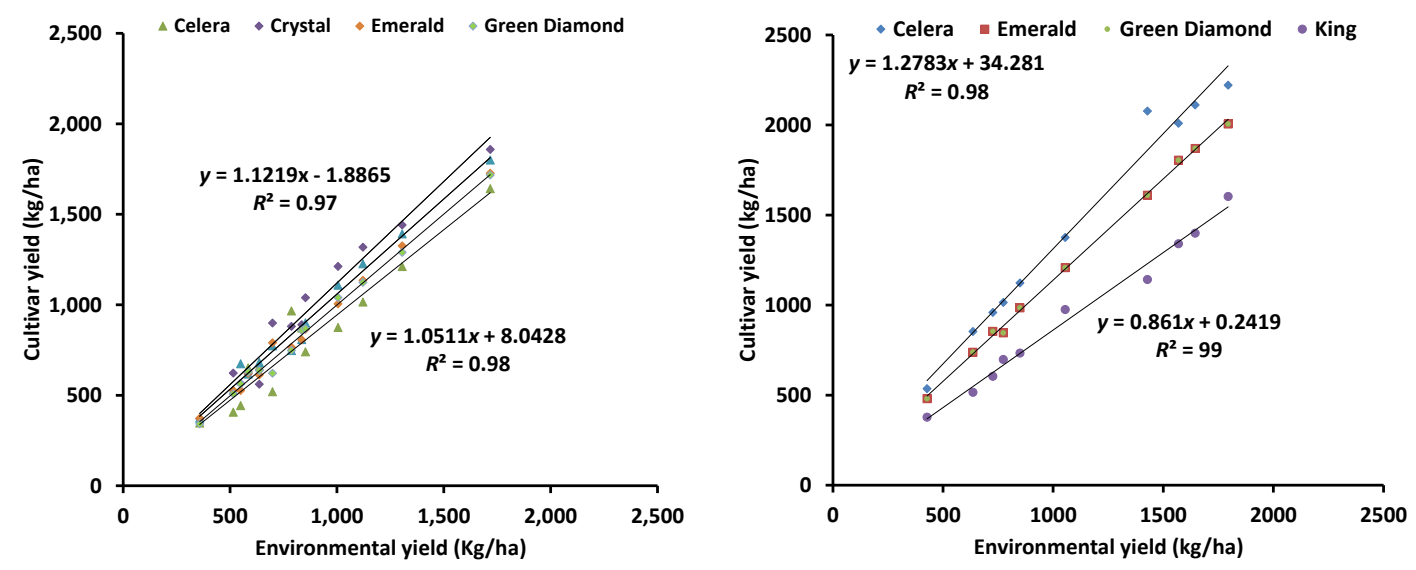

Figure 6. An example of the extent of $\mathrm{G} \times \mathrm{E}$ interactions in a mungbean trial with common cultivars (left panel) in multi-location trials and simulated (right panel) by the improved APSIM mungbean model [48].

\section{Growing Environments of Northern Australia-Main Features}

In the preceding section, it was mentioned that the growing environment has a profound influence on dry matter production and its partitioning into yield in mungbean. Environment was shown to account for over $70 \%$ of the variation in yield in international mungbean trials [85]. Knowledge of the key environmental attributes controlling yield, therefore, is essential to progress consistent and reliable yield improvements in mungbean. Lawn and Imrie [12] also emphasised the need to characterise the Australian target population of environments for mungbean to help prioritise research areas.

Chauhan and Rachaputi [37] characterised mungbean growing environments using the APSIM mungbean model. They used a time series of percentile ranks of long-term APSIM simulated yield to define agro-ecological regions. Using the model, mungbean growing areas could be subdivided into seven agro-ecological regions. With further application of the model to simulate supply demand ratio-a measure of drought intensity, the type of drought environments and their frequencies were deduced for each region. Similarly, average temperatures were extracted during different stages of the crop growth from the same output. The application of the model in this manner produced an idea of types and frequencies of drought and thermal regimes for mungbean in Australia. This modelling application has allowed identification of agro-ecological regions that are homogeneous with respect to these constraints. This approach has also been previously used to characterise sorghum growing environments in Australia [86].

Chauhan and Rachaputi [37] also found that there are four types of drought environments that mungbean experiences in the northern region (Figure 7A). These included a no stress type occurring 
in $33 \%$ of seasons, a mid-season stress type occurring in $17.1 \%$, a moderate terminal stress type occurring in $24.9 \%$, and a severe terminal stress type occurring in $25 \%$. The detrimental effects of terminal drought on mungbean growth tends to start well before flowering, and may affect canopy development. In some years, mid-season drought may encourage the formation of a second flush of flowers due to improvement in soil moisture status in the later part of the reproductive phase [9]. However, in such years, this later second flush of flowers and resultant pods is at greater risk of weather damage and potentially large reductions in mungbean seed quality [87].
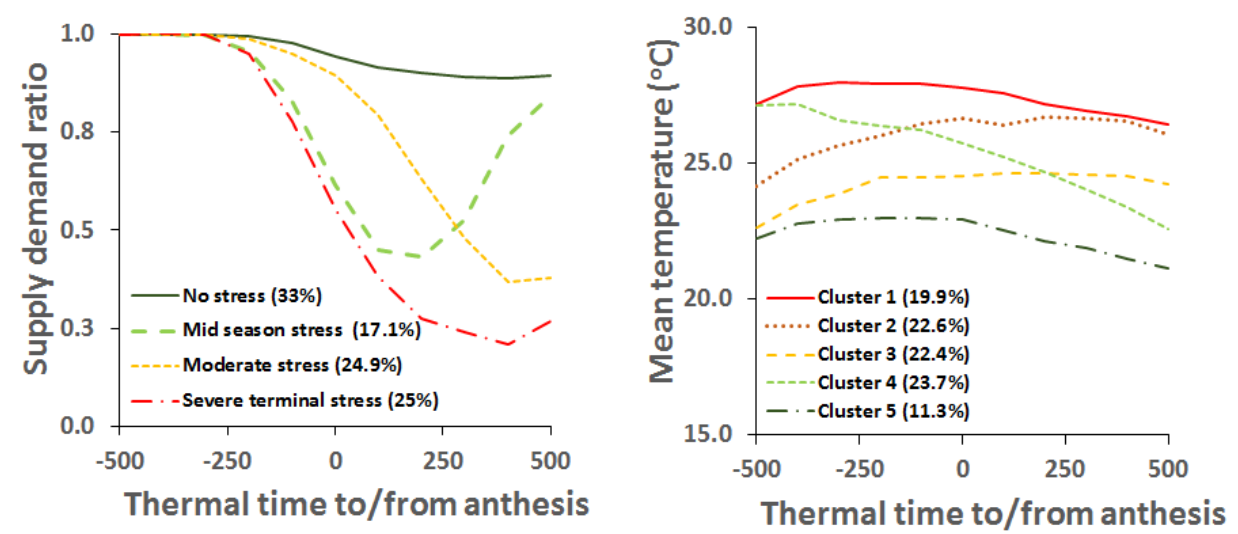

Figure 7. Categories and frequencies of drought $(\mathbf{A})$ and thermal regimes $(\mathbf{B})$ in the northern grains regions [37]. Major drought stress patterns are no-stress, mid-season stress (mid-seas.), moderate terminal stress (mod-stress), and severe terminal stress (severe-terminal stress) based on APSIM simulated supply demand ratio (SDR) averaged every $100{ }^{\circ} \mathrm{C} \mathrm{d}$. An SDR of one indicates no stress and supply matching the demand and a lower value indicates the supply demand gap. The thermal environments represent mean temperature averaged also for every $100{ }^{\circ} \mathrm{C}$. The percent occurrence of occurring different drought and thermal environment types are in inset table of each chart. Inputs used in generating these figures included site specific climatic data for 113 years and soils from 45 locations, and cultivar 'Crystal' grown at 30 plants per $\mathrm{m}^{2}$ sown with a rule-based criteria.

The optimum temperature for mungbean growth is 28 to $30^{\circ} \mathrm{C}$ [88] and although the crop has a base temperature of around $7.5^{\circ} \mathrm{C}$, it requires average soil temperatures of $>15^{\circ} \mathrm{C}$ for effective germination. Mungbean does not tolerate high temperatures above $40^{\circ} \mathrm{C}$ during the reproductive stage with major reduction in pollen viability [89].

There are five types of thermal environments that mungbean experiences in the northern grains region in Australia (Figure 7B). These thermal environments were average ambient temperature for each $100{ }^{\circ} \mathrm{C} \mathrm{d}$ during crop growth-as for drought [37]. In most situations, average temperatures remained less than the optimum, but trends differ. In some cases, temperatures started and increased during crop growth and development. In other cases, temperatures decreased during crop growth.

A key finding of this work was that agro-ecological regions defined using the percentile ranks of yield [37] tended to have similar frequencies of drought and thermal regimes within their locations. Hence, cultivars tested at different locations within an agro-ecological region would experience similar thermal regimes. As all locations within particular agro-ecological regions were geographically contiguous, they will also experience similar photoperiods. The partitioning of variation in yield according agro-ecological regions should reduce $G \times E$ interactions. Thus, this approach could rationalise testing sites depending upon whether the primary breeding objective was to select specifically or widely adapted cultivars.

Given that the Australian mungbean industry is relatively small compared to that for other grains, and hence cannot afford to maintain and produce seed of a large number of cultivars, the development of widely adapted cultivars is likely to be a preferred goal for breeders into the future. The development of widely adapted cultivars will require testing in at least one location of each agro-ecological region 
to enable the sampling of the greatest range of the target population of environments. One of the advantages of environment characterisation is that it gives scope to identify and create managed stresses similar to those that exist in nature e.g., drought or heat [90]. This also allows the definition of 'adaptation domains' for newly developed cultivars.

The agro-ecological regions defined by Chauhan and Rachaputi [37] are based on climate data from the past 113 years. The averages of drought and thermal regimes using this approach even out extremes and do not show the effect of climate change. However, a consistent trend in movement for percentile rank above or below the lowest rank over a period could indicate if climate change is occurring in a particular region. Such information will be useful for setting crop improvement priorities for different agro-ecological regions under the scenario of a changing climate.

\section{Agronomic Innovations in Mungbean Production}

In developing countries, most mungbean production is by smallholder farmers, who can get consistent yields by hand-harvesting multiple flushes of pods. This type of production, however, is unsuitable for intensive production systems in Australia where cultivation is highly mechanised. Here, mungbean is grown in wider rows of about $100 \mathrm{~cm}$. Rachaputi, Chauhan, Douglas, Martin, Krosch, Agius, and King [24] using field experiments and modelling projections showed mungbean planted at narrower row spacing of $50 \mathrm{~cm}$ produced higher yields than mungbeans sown in wide rows for $95 \%$ of the seasons in different locations (Figure 8). A key advantage of this arrangement is that planting in narrow rows reduces evaporative soil losses, but increases overall water use through transpiration and therefore, water use efficiency.
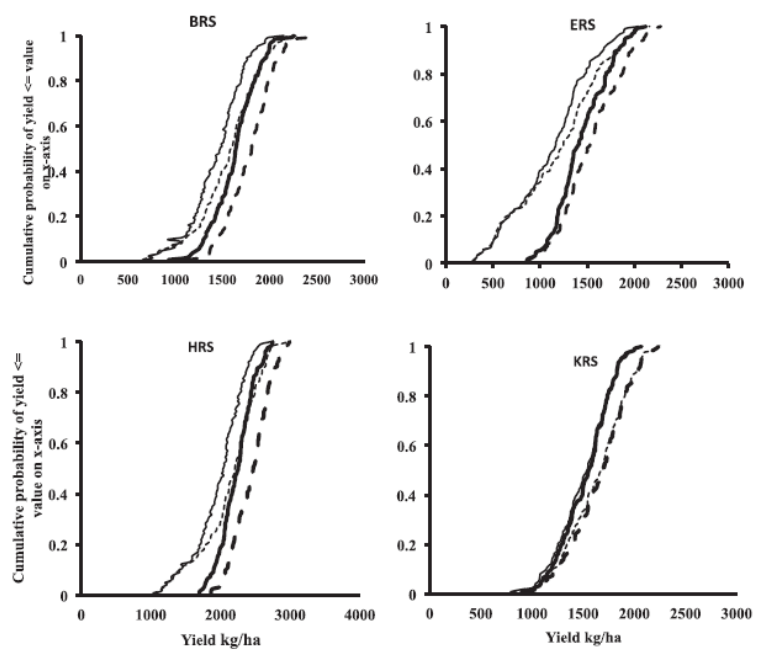

Figure 8. Cumulative probability of simulated yield distributions for the mungbean cultivar 'Crystal' at different row and starting moistures across four sites. Planting at 50\% total plant-available water holding capacity (PAWC) in wide rows $(1 \mathrm{~m})$ is shown with thin continuous lines, and narrow rows $(0.5 \mathrm{~m})$ with thin dash lines, or at $100 \%$ PAWC with wide (thick continuous lines) and narrow rows (thick dash lines). The four sites are Biloela (BRS), Emerald (ERS), Hermitage (HRS), and Kingaroy (KRS). Yields were simulated for rain-fed crop using site-specific soil properties and historical climate data over 123 years [24].

Another avenue to increase mungbean yields in mechanised production is to increase plant population. Given mungbean is a short-statured and short duration plant its response to plant population is expected to be substantial. However, response to changes in plant density have been shown to be dependent on the choice of cultivar [43,62]. Varietal differences in response to plant population in mungbean were also reported by [91]. It is possible that in 'responsive cultivars', main stems contribute relatively more to grain yield than branches. While branching is an important trait 
for crop plasticity in mungbean, limiting the number of branches may be necessary to maximise yield under closer planting.

Another innovation towards improving mungbean production in Australia is its larger-scale cultivation as a spring season crop [8]. One of the advantages of spring planting is that the mungbean crop produces considerably more dry matter. A major limitation of spring sowing, however, is that the crop matures when temperatures become very high and day length is increasing, thereby affecting reproductive development. In most cases, this will lead to a poor first flush of pods and the formation of higher proportion of second flush pods. To make spring mungbean a more viable crop option, we need to identify traits that make it more productive in the spring season. Heat tolerance is one such obvious trait [92]. Growing mungbean as a spring crop is becoming common in Asia [93] and could be further encouraged in Australia as well. This could ensure greater consistency of seed supplies to markets as well as greater flexibility in growing mungbean over different summer months.

\section{Conclusions and Future Research Directions}

Conventional plant breeding and innovative agronomic research in Australia has transformed mungbean from a small crop used in subsistence agriculture to a highly profitable, broad-scale grain crop ideally suited for mechanised production. New cultivars such as 'Crystal', 'Satin II', and 'Jade-AU' have increased productivity and grower confidence in the crop.

Future challenges remain to further enhancing yield and reliability in mungbean and to support expansion into new production areas currently marginal for its production. This will require strategic research in breeding and agronomy. Several significant research initiatives have been highlighted in this review. For example, the production of multiple flushes of pods may be a useful trait in subsistence agriculture, however, this trait creates more problems than advantages in mechanised farming. The production of multiple flushes of flowers and pods can be reduced by increasing harvest index, which should also enhance grain yield and stability in mungbean. Yield increases achieved using dry matter traits alone are more prone to variability from frequent fluctuations in water availability.

In addition, we should test new cultivars in managed or natural stress environments that closely represent the target population of environments. Environmental characterisation undertaken in this crop should assist in achieving this objective, as well as determining the adaptation domain of new cultivars. These approaches could lead to the development of cultivars with well-defined physiological traits for adapting to the target population of environments. In this review, we have not discussed strategies that may be required to develop cultivars that are more resistant of abiotic stresses. However, the principles of environment characterisation for mungbean discussed here could assist in identifying risk profiles and setting research priorities for different abiotic stresses.

Acknowledgments: We compiled this review as part of the project "Tropical Pulses for Queensland", Queensland University of Technology funded by Queensland Government from 2013 to 2016. The authors would like to thank R.J. Lawn, James Cook University, Australia, and two anonymous reviewers for making constructive suggestions on this manuscript.

Conflicts of Interest: The authors declare no conflicts of interest.

\section{References}

1. Nair, R.M.; Yang, R.Y.; Easdown, W.J.; Thavarajah, D.; Thavarajah, P.; Hughes, J.D.A.; Keatinge, J. Biofortification of mungbean (Vigna radiata) as a whole food to enhance human health. J. Sci. Food Agric. 2013, 93, 1805-1813. [CrossRef] [PubMed]

2. Peoples, M.; Brockwell, J.; Herridge, D.; Rochester, I.; Alves, B.; Urquiaga, S.; Boddey, R.; Dakora, F.; Bhattarai, S.; Maskey, S. The contributions of nitrogen-fixing crop legumes to the productivity of agricultural systems. Symbiosis 2009, 48, 1-17. [CrossRef]

3. Ebert, A.W. Potential of underutilized traditional vegetables and legume crops to contribute to food and nutritional security, income and more sustainable production systems. Sustainability 2014, 6, 319-335. [CrossRef] 
4. Keatinge, J.; Easdown, W.; Yang, R.; Chadha, M.; Shanmugasundaram, S. Overcoming chronic malnutrition in a future warming world: The key importance of mungbean and vegetable soybean. Euphytica 2011, 180, 129-141. [CrossRef]

5. Tang, D.; Dong, Y.; Ren, H.; Li, L.; He, C. A review of phytochemistry, metabolite changes, and medicinal uses of the common food mung bean and its sprouts (Vigna radiata). Chem. Cent. J. 2014, 8, 4. [CrossRef] [PubMed]

6. Alexandratos, N.; Bruinsma, J. World Agriculture towards 2030/2050: The 2012 Revision; ESA Working Paper; FAO: Rome, Italy, 2012.

7. Lawn, R.; Russell, J. Mungbean: A grain legume for summer rainfall cropping areas of Australia. J. Aust. Inst. Agric. Sci. 1978, 44, 28-41.

8. Robertson, M.; Carberry, P.; Lucy, M. Evaluation of a new cropping option using a participatory approach with on-farm monitoring and simulation: A case study of spring-sown mungbeans. Aust. J. Agric. Res. 2000, 51, 1-12. [CrossRef]

9. Thomas Robertson, M.J.; Fukai, S.; Peoples, M.B. The effect of timing and severity of water deficit on growth, development, yield accumulation and nitrogen fixation of mungbean. Field Crops Res. 2004, 86, 67-80. [CrossRef]

10. Amarasingha, R.; Suriyagoda, L.; Marambe, B.; Rathnayake, W.; Gaydon, D.; Galagedara, L.; Punyawardena, R.; Silva, G.; Nidumolu, U.; Howden, M. Improving water productivity in moisture-limited rice-based cropping systems through incorporation of maize and mungbean: A modelling approach. Agric. Water Manag. 2017, 189, 111-122. [CrossRef]

11. Col Douglas. DAF, Hermitage, Qld, Australia. Personal communication. 2017.

12. Lawn, R.; Imrie, B. Crop improvement for tropical and subtropical Australia: Designing plants for difficult climates. Field Crops Res. 1991, 26, 113-139. [CrossRef]

13. Singh, H.; Joshi, B.; Thomas, T. The phaseolus group. In Pulse Crops of India'; Kachroo, P., Ed.; Indian Council of Agricultural Research: New Delhi, India, 1970; pp. 136-164.

14. Smartt, J. Evolution of grain legumes. III. Pulses in the genus Vigna. Exp. Agric. 1985, 21, 87-100. [CrossRef]

15. Lukoki, L.; Marechal, R.; Otoul, E. Les ancetres sauvages des haricots cultives: Vigna radiata (L.) Wilczek et V. mungo (L.) Hepper. Bull. Jard. Bot. Natl. Belg./Bull. Natl. Plantentuin Belg. 1980, 50, 385-391. [CrossRef]

16. Abbas, G.; Hameed, A.; Rizwan, M.; Ahsan, M.; Asghar, M.J.; Iqbal, N. Genetic confirmation of mungbean (Vigna radiata) and mashbean (Vigna mungo) interspecific recombinants using molecular markers. Front. Plant Sci. 2015, 6, 1107. [CrossRef] [PubMed]

17. Yimram, T.; Somta, P.; Srinives, P. Genetic variation in cultivated mungbean germplasm and its implication in breeding for high yield. Field Crops Res. 2009, 112, 260-266. [CrossRef]

18. Gwag, J.G.; Chung, J.W.; Chung, H.K.; Lee, J.H.; Ma, K.H.; Dixit, A.; Park, Y.J.; Cho, E.G.; Kim, T.S.; Lee, S.H. Characterization of new microsatellite markers in mung bean, Vigna radiata (L.). Mol. Ecol. Resour. 2006, 6, 1132-1134. [CrossRef]

19. Kim, S.K.; Nair, R.M.; Lee, J.; Lee, S.-H. Genomic resources in mungbean for future breeding programs. Front. Plant Sci. 2015, 6, 626. [CrossRef] [PubMed]

20. Lambrides, C.; Godwin, I. Mungbean. In Pulses, Sugar and Tuber Crops; Springer: Berlin/Heidelberg, Germany, 2007; pp. 69-90.

21. Shanmugasundaram, S.; Keatinge, J.; d Arros Hughes, J. The Mungbean Transformation Diversifying Crops, Defeating Malnutrition; International Food Policy Research Institute: Washington, DC, USA, 2009; Volume 922.

22. Martre, P.; Quilot-Turion, B.; Luquet, D.; Memmah, M.-M.O.-S.; Chenu, K.; Debaeke, P. Model-assisted phenotyping and ideotype design. In Crop Physiology, 2nd ed.; Elsevier: New York, NY, USA, 2015; pp. 349-373.

23. Kang, Y.J.; Kim, S.K.; Kim, M.Y.; Lestari, P.; Kim, K.H.; Ha, B.-K.; Jun, T.H.; Hwang, W.J.; Lee, T.; Lee, J. Genome sequence of mungbean and insights into evolution within Vigna species. Nat. Commun. 2014, 5, 5443. [CrossRef] [PubMed]

24. Rachaputi, R.C.; Chauhan, Y.; Douglas, C.; Martin, W.; Krosch, S.; Agius, P.; King, K. Physiological basis of yield variation in response to row spacing and plant density of mungbean grown in subtropical environments. Field Crops Res. 2015, 183, 14-22. [CrossRef] 
25. Harris, D.; Breese, W.; Rao, J.K. The improvement of crop yield in marginal environments using 'on-farm'seed priming: Nodulation, nitrogen fixation, and disease resistance. Aust. J. Agric. Res. 2005, 56, 1211-1218. [CrossRef]

26. Cook, S.; Gupta, S.; Woodhead, T.; Larson, W. Soil physical constraints to establishment of mungbeans (Vigna radiata L. Wilczek) in paddy rice (Oryza sativa L.) soils. Soil Tillage Res. 1995, 33, 47-64. [CrossRef]

27. Abrecht, D. No-till crop establishment on red earth soils at Katherine, Northern Territory: Effect of sowing depth and firming wheel pressure on the establishment of cowpea, mung bean, soybean and maize. Aust. J. Exp. Agric. 1989, 29, 397-402. [CrossRef]

28. TeKrony, D.M.; Egli, D.B. Relationship of seed vigor to crop yield: A review. Crop Sci. 1991, 31, 816-822. [CrossRef]

29. Armstrong, R.; McCosker, K.; Johnson, S.; Millar, G.; Walsh, K.; Kuskopf, B.; Probert, M.; Standley, J. Legume and opportunity cropping systems in central Queensland. 1. Legume growth, nitrogen fixation, and water use. Aust. J. Agric. Res. 1999, 50, 909-924. [CrossRef]

30. Summerfield, R.; Lawn, R. Environmental modulation of flowering in mung bean (Vigna radiata): A reappraisal. Exp. Agric. 1987, 23, 461-470. [CrossRef]

31. Robertson, M.; Carberry, P.; Huth, N.; Turpin, J.; Probert, M.E.; Poulton, P.; Bell, M.; Wright, G.; Yeates, S.; Brinsmead, R. Simulation of growth and development of diverse legume species in APSIM. Aust. J. Agric. Res. 2002, 53, 429-446. [CrossRef]

32. Summerfield, R.; Lawn, R. Environmental modulation of flowering in mung bean (Vigna radiata): Further reappraisal for diverse genotypes and photothermal regimes. Exp. Agric. 1988, 24, 75-88. [CrossRef]

33. Carberry, P.; Muchow, R.; Williams, R.; Sturtz, J.; McCown, R. A simulation model of kenaf for assisting fibre industry planning in northern Australia. I. General introduction and phenological model. Aust. J. Agric. Res. 1992, 43, 1501-1513. [CrossRef]

34. Rebetzke, G.; Lawn, R. Adaptive responses of wild mungbean (Vigna radiata ssp. sublobata) to photo-thermal environment. II.* Growth, biomass, and seed yield. Aust. J. Agric. Res. 2006, 57, 929-937. [CrossRef]

35. Imrie, B.; Lawn, R. Time to flowering of mung bean (Vigna radiata) genotypes and their hybrids in response to photoperiod and temperature. Exp. Agric. 1990, 26, 307-318. [CrossRef]

36. Ellis, R.; Lawn, R.; Summerfield, R.; Qi, A.; Roberts, E.; Chay, P.; Brouwer, J.; Rose, J.; Yeates, S.; Sandover, S. Towards the reliable prediction of time to flowering in six annual crops. IV. Cultivated and wild mung bean. Exp. Agric. 1994, 30, 31-43. [CrossRef]

37. Chauhan, Y.; Rachaputi, R.C. Defining agro-ecological regions for field crops in variable target production environments: A case study on mungbean in the northern grains region of Australia. Agric. For. Meteorol. 2014, 194, 207-217. [CrossRef]

38. Rawson, H.; Craven, C. Variation between short duration mungbean cultivars (Vigna radiata (L.) Wilczek) in response to temperature and photoperiod. Indian J. Plant Physiol. 1979, 22, 127-136.

39. Wallace, D.; Zobel, R.; Yourstone, K. A whole-system reconsideration of paradigms about photoperiod and temperature control of crop yield. Theor. Appl. Genet. 1993, 86, 17-26. [CrossRef] [PubMed]

40. Lee, Y.S.; Lee, J.Y.; Kim, D.K.; Yoon, C.Y.; Bak, G.C.; Park, I.J.; Bang, G.P.; Moon, J.K.; Oh, Y.J.; Min, K.S. A new high-yielding mungbean cultivar," Samgang" with lobed leaflet. Kor. Breed. J. 2004, 36, 183-184.

41. Muchow, R.; Robertson, M.; Pengelly, B. Accumulation and partitioning of biomass and nitrogen by soybean, mungbean and cowpea under contrasting environmental conditions. Field Crops Res. 1993, 33, 13-36. [CrossRef]

42. Muchow, R. Canopy development in grain legumes grown under different soil water regimes in a semi-arid tropical environment. Field Crops Res. 1985, 11, 99-109. [CrossRef]

43. Muchow, R.; Charles-Edwards, D. An analysis of the growth of mung beans at a range of plant densities in tropical Australia. I. Dry matter production. Aust. J. Agric. Res. 1982, 33, 41-51. [CrossRef]

44. Kuo, C.; Wang, L.; Cheng, A.; Chou, M. Physiological basis for mungbean yield improvement. In Proceedings of the International Mungbean Symposium, Los Banos, Philippines, 16-19 August 1977.

45. Lawn, R. Response of four grain legumes to water stress in south-eastern Queensland. II. Plant growth and soil water extraction patterns. Aust. J. Agric. Res. 1982, 33, 497-509. [CrossRef]

46. Robertson, M.; Carberry, P.; Wright, G.; Singh, D. Using models to assess the value of traits of food legumes from a cropping systems perspective. In Linking Research and Marketing Opportunities for Pulses in the 21st Century; Springer: Berlin/Heidelberg, Germany, 2000; pp. 265-278. 
47. Muchow, R. An analysis of the effects of water deficits on grain legumes grown in a semi-arid tropical environment in terms of radiation interception and its efficiency of use. Field Crops Res. 1985, 11, 309-323. [CrossRef]

48. Chauhan, Y.; Douglas, C.; Rachaputi, R.; Agius, P.; Martin, W.; King, K.; Skerman, A. Physiology of mungbean and development of the mungbean crop model. In Proceedings of the 1st Australian Summer Grains Conference, Gold Coas, Australia, 21-24 June 2010.

49. Muchow, R.; Robertson, M.; Pengelly, B. Radiation-use efficiency of soybean, mugbean and cowpea under different environmental conditions. Field Crops Res. 1993, 32, 1-16. [CrossRef]

50. Lawn, R. Agronomic and physiological constraints to the productivity of tropical grain legumes and prospects for improvement. Exp. Agric. 1989, 25, 509-528. [CrossRef]

51. Lawn, R. Response of four grain legumes to water stress in south-eastern Queensland. III. Dry matter production, yield and water use efficiency. Aust. J. Agric. Res. 1982, 33, 511-521. [CrossRef]

52. Dodt, M.G. Characterisation of Root Architectural Responses of Mungbean to Water Deficit; Queensland University of Technology: Brisbane, Australia, 2017.

53. Singh, D.; Singh, B. Breeding for tolerance to abiotic stresses in mungbean. J. Food Legum. 2011, 24, 83-90.

54. Bushby, H.; Lawn, R. Accumulation and partitioning of nitrogen and dry matter by contrasting genotypes of mungbean (Vigna radiata (L.) Wilczek). Aust. J. Agric. Res. 1992, 43, 1609-1628. [CrossRef]

55. Cui, S.; Yu, D. Estimates of relative contribution of biomass, harvest index and yield components to soybean yield improvements in China. Plant Breed. 2005, 124, 473-476. [CrossRef]

56. Duncan, W.; McCloud, D.; McGraw, R.; Boote, K. Physiological aspects of peanut yield improvement. Crop Sci. 1978, 18, 1015-1020. [CrossRef]

57. Gifford, R.M.; Thorne, J.; Hitz, W. Crop productivity and photoassimilate partitioning. Science 1984, 225, 801-808. [CrossRef] [PubMed]

58. Hay, R. Harvest index: A review of its use in plant breeding and crop physiology. Ann. Appl. Biol. 1995, 126, 197-216. [CrossRef]

59. Lawn, R.J. Contributions to Crop Improvement and Sustainable Agriculture in Tropical and Subtropical Australia; The University of Queensland: Brisbane, Australia, 2004.

60. Lawn, R. Response of four grain legumes to water stress in south-eastern Queensland. I. Physiological response mechanisms. Aust. J. Agric. Res. 1982, 33, 481-496. [CrossRef]

61. Lawn, R.; Williams, J. Limits imposed by climatological factors, Food Legume improvement for Asian farming systems. proceedings of an international workshop, Khon Kaen, Thailand, 1987; Wallis, E., Byth, D., Eds.; pp. 83-89.

62. Muchow, R.; Charles-Edwards, D. An analysis of the growth of mung beans at a range of plant densities in tropical Australia. II. Seed production. Aust. J. Agric. Res. 1982, 33, 53-61. [CrossRef]

63. Imrie, B.; Butler, K. An analysis of variability and genotype $\times$ environment interaction in mung bean (Vigna radiata) in south-eastern Queensland. Aust. J. Agric. Res. 1982, 33, 523-530. [CrossRef]

64. Lawn, R. Agronomic studies on Vigna spp. in south-eastern Queensland. I. Phenological response of cultivars to sowing date. Aust. J. Agric. Res. 1979, 30, 855-870. [CrossRef]

65. Lawn, R. Agronomic studies on Vigna spp. in south-eastern Queensland. II. Vegetative and reproductive response of cultivars to sowing date. Aust. J. Agric. Res. 1979, 30, 871-882. [CrossRef]

66. Rebetzke, G.; Lawn, R. Adaptive responses of wild mungbean (Vigna radiata ssp. sublobata) to photo-thermal environment. I.* Phenology. Aust. J. Agric. Res. 2006, 57, 917-928. [CrossRef]

67. Inouye, J.; Shanmugasundaram, S. Photoperiod and temperature effects on the growth and reproductive behaviour of less photoperiod sensitive soybeans. Soybeans Trop. Sub-Trop. Crop. Syst. 1984, 354-360.

68. Rowell, T.; Mortley, D.; Loretan, P.; Bonsi, C.; Hill, W. Continuous daily light period and temperature influence peanut yield in nutrient film technique. Crop Sci. 1999, 39, 1111-1114. [CrossRef]

69. Chauhan, Y.; Venkataratnam, N.; Sheldrake, A. Factors affecting growth and yield of short-duration pigeonpea and its potential for multiple harvests. J. Agric. Sci. 1987, 109, 519-529. [CrossRef]

70. Saxena, K.; Gupta, S.; Sharma, D.; Reddy, L.; Chauhan, Y.; Kannaiyan, J.; Green, J.; Nene, Y.; Faris, D. Registration of ICPL 87 pigeonpea. Crop Sci. 1989, 29, 237-237. [CrossRef]

71. Chauhan, Y.; Johansen, C.; Moon, J.-K.; Lee, Y.-H.; Lee, S.-H. Photoperiod responses of extra-short-duration pigeonpea lines developed at different latitudes. Crop Sci. 2002, 42, 1139-1146. [CrossRef] 
72. Lawn, R.; James, A. Application of physiological understanding in soybean improvement. I. Understanding phenological constraints to adaptation and yield potential. Crop Pasture Sci. 2011, 62, 1-11. [CrossRef]

73. James, A.; Lawn, R. Application of physiological understanding in soybean improvement. II. Broadening phenological adaptation across regions and sowing dates. Crop Pasture Sci. 2011, 62, 12-24. [CrossRef]

74. Bashandi, M.M.; Poehlman, J.T. Photoperiod response in mungbeans (Vigna radiata (L.) Wilczek). Euphytica 1974, 23, 691-697. [CrossRef]

75. Major, D.; Kiniry, J.; Hodges, T. Predicting day length effects on phenological processes. In Predicting Crop Phenology; CRC Press: Boca Raton, FL, USA, 1991; pp. 15-28.

76. Vergara, B.S.; Chang, T.-T. The Flowering Response of the Rice Plant to Photoperiod: A Review of the Literature; International Rice Reseach Institute: Los Banos, Philippines, 1985.

77. Takeno, K. Epigenetic regulation of photoperiodic flowering. Plant Signal. Behav. 2010, 5, 788-791. [CrossRef] [PubMed]

78. Alam Mondal, M.M.; Ali Fakir, M.S.; Juraimi, A.S.; Hakim, M.; Islam, M.; Shamsuddoha, A. Effects of flowering behavior and pod maturity synchrony on yield of mungbean ['Vigna radiata' (L.) Wilczek]. Aust. J. Crop Sci. 2011, 5, 945.

79. Clifford, P. Control of reproductive sink yield in mung beans. Z. Pflanzenphysiol. 1981, 102, $173-181$. [CrossRef]

80. H. Brier. DAF, Kingaroy, Qld, Australia. Personal communication. 2017.

81. Roberts, E.; Hadley, P.; Summerfield, R. Effects of temperature and photoperiod on flowering in chickpeas (Cicer arietinum L.). Ann. Bot. 1985, 55, 881-892. [CrossRef]

82. Saxena, K.; Sultana, R.; Mallikarjuna, N.; Saxena, R.; Kumar, R.; Sawargaonkar, S.; Varshney, R. Male-sterility systems in pigeonpea and their role in enhancing yield. Plant Breed. 2010, 129, 125-134. [CrossRef]

83. Imrie, B.; Drake, D.; Delacy, I.; Byth, D. Analysis of genotypic and environmental variation in international mungbean trials. Euphytica 1981, 30, 301-311. [CrossRef]

84. Swindell, R.E.; Poehlman, J. Inheritance of photoperiod response in mungbean (Vigna radiata [L.] Wilczek). Euphytica 1978, 27, 325-333. [CrossRef]

85. Imrie, B.; Shanmugasundaram, S. Source of variation in yield in international mungbean trials. Field Crops Res. 1987, 16, 197-208. [CrossRef]

86. Chapman, S.C.; Cooper, M.; Hammer, G.L. Using crop simulation to generate genotype by environment interaction effects for sorghum in water-limited environments. Aust. J. Agric. Res. 2002, 53, 379-389. [CrossRef]

87. Williams, R. A Study of the Causes of, and Selection for Resistance to, Weather Damage in Mungbean (Vigna radiata (L.) Wilczek; V. mungo (L.) Hepper). Ph.D. Thesis, The University of Queensland, Brisbane, Australia, 1989.

88. Poehlman, J. The Mung Bean; Oxford and IBH Publication Co. Pvt. Ltd.: New Delhi, India, 1991; pp. 27-29.

89. Kaur, R.; Bains, T.; Bindumadhava, H.; Nayyar, H. Responses of mungbean (Vigna radiata L.) genotypes to heat stress: Effects on reproductive biology, leaf function and yield traits. Sci. Hortic. 2015, 197, 527-541. [CrossRef]

90. Sharma, L.; Priya, M.; Bindumadhava, H.; Nair, R.; Nayyar, H. Influence of high temperature stress on growth, phenology and yield performance of mungbean [Vigna radiata (L.) Wilczek] under managed growth conditions. Sci. Hortic. 2016, 213, 379-391. [CrossRef]

91. Pookpakdi, A.; Pataradilok, H. Response of genotypes of mungbean and blackgram to planting dates and plant population densities. Kasetsart J. Nat. Sci 1993, 27, 395-400.

92. Patriyawaty, N.R.; Rachaputi, R.C.; George, D. Physiological mechanisms underpinning tolerance to high temperature stress during reproductive phase in mungbean (Vigna radiata (L.) Wilczek). Environ. Exp. Bot. 2018, 150, 188-197. [CrossRef]

93. Ali, M.; Kumar, S. Prospects of mungbean in rice-wheat cropping systems in Indo-Gangetic Plains of India. In Improving Income and Nutrition by Incorporating Mungbean in the Cereal Fallows of the Indo-Gangetic Plains of South Asia; Proceedings of the Final Workshop and Planning Meeting; AVRDC-The World Vegetable Center: Tainan, Taiwan, 2004; pp. 246-254.

(C) 2018 by the authors. Licensee MDPI, Basel, Switzerland. This article is an open access article distributed under the terms and conditions of the Creative Commons Attribution (CC BY) license (http://creativecommons.org/licenses/by/4.0/). 